\title{
DĚDICTVÍ KLEMENTINSKÝCH EXAKTNÍCH VĚD A DRUHÝ ŽIVOT „MATEMATICKÉHO MUZEA“ V 19. A 20. STOLETÍ
}

\author{
PETRA HYKLOVÁ
}

\section{THE LEGACY OF EXACT SCIENCES IN THE CLEMENTINUM AND SECOND LIFE OF THE "MUSAEUM MATHEMATICUM" IN THE NINETEENTH AND TWENTIETH CENTURY}

Activities of the Society of Jesus in the Clementinum had ended with the dissolution of the Order in 1773, whereupon the Clementinum became a secular building. Save for a few exceptions, data gathered by the Jesuits did not survive. In the nineteenth and twentieth century, historians of science therefore had to rely on the study of extant instruments and on publications that had appeared in print. The aim of this contribution is to describe the contribution of earlier historians of science, such as Josef Smolík, Quido Vetter, Otto Seydl, and Zdeněk Horský, to our knowledge of scientific activities in the Clementinum.

Keywords: Musaeum mathematicum - Clementinum - Josef Smolík - Quido Vetter - Otto Seydl - Zdeněk Horský

DOI: $10.14712 / 23365730.2018 .49$

\section{Dochovaná data a publikace}

Vědecká činnost jezuitů nebyla prioritním úkolem řádu a byla spojena s činností misionářskou a pedagogickou. Jezuitské školy byly otevřeny veřejnosti, nejen členům řádu, a do roku 1618 i nekatolíkům. ${ }^{1}$ Jejich hlavním zaměřením byla teologie, misijní činnost však vyžadovala dobré všeobecné vzdělání a exaktní vědy v něm měly význačné místo. ${ }^{2}$ Výzkumná data nashromážděná jezuity se nedochovala až na výjimky, k nimž patří klementinská meteorologická řada. Její počátky byly publikovány jako př́loha ke spisu Josepha Steplinga (1716-1778) De pluvia lapidea ... ${ }^{3} \mathrm{z}$ roku 1754.

Přehled spisů, které prokazatelně aspoň zčásti vznikly v Klementinu, podává Schuppener ${ }^{4}$ nebo Mačák a Schuppener. ${ }^{5}$ Tyto spisy jsou obvykle označeny jako „matematické“, čímž je míněna matematika $v$ tehdejším pojetí ${ }^{6}$ a zejména matematika jezuitská, jež navíc

1 Ivana ČornejovÁ, Tovaryšstvo Ježíšovo. Jezuité v Čechách, Praha 1995, s. 66.

2 Znalosti astronomie, matematiky a umění usnadnily působení misionářủ v Číně. Velké rozšíření zaznamenalo křest’anství za působení P. J. A. Schalla von Bella, který pomohl reformovat čínský kalendář.

3 Joseph Stepling, De Pluvia Lapidea Anni M.DCC.LIII. ad Strkow et ejus Causis Meditatio, Praha 1754.

4 Georg SchupPenER, Jesuitische Mathematik in Prag im 16. und 17. Jahrhundert (1556-1654), Leipzig 1999.

5 Karel MAČÁK - Georg SchupPEner, Matematika v jezuitském Klementinu v letech 1600-1740, Praha 2001.

6 Tradiční středověké quadrivium zahrnuje aritmetiku, geometrii, astronomii a musiku (nauka o číselných poměrech výšek tónů v hudebních intervalech). 
zahrnuje katoptriku ${ }^{7}$, dioptriku ${ }^{8}$ a pro Klementinum typickou gnomoniku. ${ }^{9}$ Většina spisů ze 17. a první poloviny 18. století se matematiky týkala jen okrajově nebo vůbec. Převažují spisy vztahující se $\mathrm{k}$ výuce - rukopisné záznamy přednášek a tištěné „,disertace“. „Disertace“, případně ,these“ byly obhajovány za účelem veřejného cvičení během studia, na závěr studia nebo pro dosažení akademické hodnosti. ${ }^{10} \mathrm{U}$ klementinských disertací není účel uveden a rovněž není jasný autorský podíl předsedajícího profesora a defendanda, podle Mačáka ${ }^{11}$ jsou však pravděpodobně všechny napsány profesory.

\section{Matematické muzeum}

V roce 1722 bylo oficiálně založeno Musaeum mathematicum Collegii Clementini. Vzorem pro toto muzeum bylo Musaeum Collegii Romani Societatis Jesu, založené v roce 1650 a spravované Athanasiem Kircherem.

Jména zakladatelů a správců muzea lze zjistit z biografií jednotlivých pražských členů řádu. Seydl ${ }^{12}$ uvádí seznam správců: Caspar Pflieger (1722-1730), Johann Klein (1732-1762), Johann Wendlinger (1767-1769), Nicolaus Krebs (1772), Franciscus Zeno (1772-1773), Joseph Stepling (1773-1774) a Antonín Strnad (1774-1785).

Po zrušení jezuitského řádu $v$ roce 1773 přešlo muzeum do světské správy a bylo přestěhováno z původních pěti místností do tř́ a částečně také do bytu Josepha Steplinga. V roce 1785 bylo zrušeno a inventár rozdělen mezi Státní hvězdárnu (astronomické a meteorologické př́stroje, globy a hodiny), Fysikální muzeum (mechanika, optika, akustika, elektřina), Královskou českou společnost nauk (přírodniny a kuriosa) a Stavovskou inženýrskou školu (mechanika, hydraulika, fyzika).

Inventáŕ muzea popisují tři dochované inventární seznamy. První pořídil Antonín Strnad v roce $1781 .{ }^{13}$ Tento seznam byl v roce 1951 publikován a přeložen Ottou Seydlem. ${ }^{14}$ Další inventární seznam pochází z 1. ř́jna 1834 a podle Seydla jej sepsal ředitel Státní hvězdárny Alois Martin David, než odešel na odpočinek do premonstrátského kláštera v Teplé; 15 dle životopisu Hlinomaze a Mildorfové však David opustil Prahu již v roce $1833 .{ }^{16}$ Tento seznam se dochoval $\mathrm{v}$ opisu pořízeném kolem roku 1844 a obsahuje inventár hvězdárny i muzea. ${ }^{17}$ Tehdejší ředitel Státní hvězdárny Karl Kreil pořídil v únoru 1846 také vlastní soupis inventáře včetně uspořádání podle místností. V letech $1852-1856$ byla na př́kaz místodržitelství část inventáře rozprodána. ${ }^{18}$ Zbylé předměty z matematického muzea

7 Nauka o odrazu světelných paprsků.

8 Nauka o lomu světelných paprsků.

9 Nauka o konstrukci slunečních hodin. Je nezávislá na používaném kosmologickém modelu.

10 Josef TřísKa, Disertace pražské univerzity 16.-18. století, Praha 1977.

11 K. MAČÁK - G. SCHuPPEnER, Matematika v jezuitském Klementinu, s. 106

12 Otto SEYd, Dějiny jesuitského, Musea matematického ‘v koleji sv. Klimenta na Starém městě v Praze, Věstník Královské české společnosti nauk, třída matematicko-př́rodovědná, 1951, č. VII, s. 3.

13 Consignatio rerum in Museo Mathematico Caesareo Regio. Die 5. Augusti 1781.

14 O. SEYdL, Dějiny, s. 45-58.

15 Tamtéž, s. 30.

16 Milan Hlinomaz - Lucie Mildorfová, Alois Martin David (8. 12.1757-28. 2. 1836). K 250. výročí narození nejvýznamnějši vědecké osobnosti Tepelska, Sborník muzea Karlovarského kraje 16, 2008, s. 123-140.

17 O. Seydu, Dějiny, s. 30.

18 Bližší rozbor viz O. SEydu, Dějiny; TÝž Prodej přistrojů Pražské hvězdárny ředitelem J. J. Böhmem r. 1856, Věstník Královské české společnosti nauk, třída matematicko-přírodovědná, 1951. 
zůstaly součástí muzea Státní hvězdárny. Z roku 1895 jsou dochovány fotografie pořízené ředitelem Ladislavem Weinekem (1848-1913).

V současnosti jsou v Barokním sále Klementina vystaveny trauttsmansdorfské hodiny z roku 1596, troje hodiny kustoda muzea a mechanika Johanna Kleina (zeměpisné, tychonské a koperníkovské) a dvanáct globů různého původu. Nejstarší globy pocházejí z Benátek z roku 1692 a jde o dvojici zeměpisného a hvězdného globu, zhotovenou Vincenzem Coronellim (1650-1718). Nachází se zde také dvojice globů prvního kustoda muzea Caspara Pfliegera - hvězdný globus z roku 1725 o průměru 127 cm s obrazy 67 souhvězdí připevněnými zvenčí na kostru, ekliptikou a rafií se symbolem Slunce v robustním dřevěném podstavci s hodinovým strojem pro otáčení; a nedokončený zeměpisný globus z roku 1730.

\section{Josef Smolík}

Josef Smolík (1832-1915) publikoval v roce 1864 rozsáhlý přehled biografií matematiků českých a v českých zemích žijících. ${ }^{19} \mathrm{~V}$ předmluvě uvádí: „Nikdo mně snad toho nezazlí, pakli spisům cizích professorů - jesuitů, u nichž se nikterak snahy nejevily, aby národ, jehož syny vyučovali, realně vzdělali a zvelebili, méně pozornosti věnuji - něco málo znamenitějšich nebo lépe řečeno zvláštnějšich vyjímaje - nežli spisům rodáki̊ našich."20

V období vymezeném založením pražské univerzity (1348) a převzetím univerzity do správy jezuitů (1622) se Smolík soustředí na biografie českých matematiků a matematiků v Čechách působících. V úvodu však poznamenává, že se „setkáváme velmi zř́idka s profesorem, který by byl rozený Čech" 21 a z toho důvodu se věnuje českým matematikům působícím mimo vlast. Mnoho prostoru věnuje Tadeáši Hájkovi z Hájku, Tychonu Brahemu a Janu Keplerovi. Publikovaná část rukopisu končí přibližně v první čtvrtině 17 . století.

\section{Quido Vetter}

Biografii Quida Vettera (1881-1960) shrnuje nepodepsaný článek k padesátiletému jubileu Vetterova působení ve školství, 22 článek L. Nového ${ }^{23}$ a nekrolog od Františka Balady. ${ }^{24}$ Zatím však neexistuje podrobnější monografie a některé části jeho životopisu jsou nejasné, např́iklad Vetterovo působení v pozici ředitele městské reálky v Humpolci ${ }^{25} \mathrm{v}$ letech 1937-1939, odkud dojížděl do Prahy konat přednášky, ${ }^{26}$ či jeho působení v poválečné době.

19 Josef Sмоцíк, Mathematikové v Čechách od založeni university Pražské až do počátku tohoto století, Praha 1864.

20 Tamtéž, s. 4.

21 Tamtéž.

22 Padesát let služby české škole a české vědě [Quido Vetter], Pokroky matematiky, fyziky a astronomie 2/6, 1957, s. 733-734.

23 Luboš NovÝ, Misto Quido Vettera v rozvoji dějin matematiky, Dějiny věd a techniky 23/3, 1990, s. 129-145.

24 František BALAdA, Zemřel univ. prof. PhDr. Quido Vetter, Pokroky matematiky, fyziky a astronomie 5/6, 1961, s. 114-115.

25 Archiv Univerzity Karlovy (dále AUK), fond Př́rodovědecká fakulta UK 1921-1953, inv. č. 154.

26 Tamtéž. 
Ve vlastním seznamu prací z roku 1952 Vetter uvádí 299 knih, pojednání a článků, 386 recenzí a 51 přednášek. ${ }^{27}$ Dějin jezuitských exaktních věd se přímo týká desetistránkový článek Vývoj matematiky v českých zemích od $r .1620$ do konce 17. stoleti ${ }^{28}$ a dvoustránkové Matematické vědy v klášterech jezovitských na půdě republiky Československé. ${ }^{29}$

Vývoj matematiky v českých zemích od $r .1620$ do konce 17. stoleti ${ }^{30}$ byl publikován posmrtně v roce 1961 a je třetí v sérii článků o české historii matematiky. ${ }^{31}$ Jako pramen pro přehled obsahu výuky matematiky v jezuitské akademii a komparaci se zahraničím Vetter použil rukopis XII G 6 a konstatuje, že ,o tehdy moderní analytické geometrii a později infinitesimálním počtu jakož i o kombinatorice nenalézáme ve spisech jezuitských akademii ani zmínky“. ${ }^{32} \mathrm{O}$ exaktních vědách se zmiňuje jen stručně na začátku článku; bez bližších podrobností nebo hodnocení píše o početných pracích z oboru astronomie, horologie a vojenské architektury a nadále se zabývá dle svých slov „,dily výlučně matematickými“ ${ }^{33}$ podává však spíš přehled významných osobností oboru a jejich děl. Hned ze začátku článku jmenuje překážky pro pěstování vědy jezuitskými učenci (časté stř́idání učebních předmětů a priorita rychlé a násilné rekatolizace českých zemí před vědeckým bádáním). Sedmnácté století hodnotí jako období úpadku matematické vědy. Na konci článku stručně shrnuje vývoj zeměměřičství jako hojně pěstovaného oboru.

Vetterův př́stup $\mathrm{k}$ historii matematiky je silně pozitivistický a personalizovaně pojatý; klade větší důraz na teoretickou než praktickou matematiku. Vetter byl v kontaktu se zahraničním vývojem a obeznámen s dílem Georgese Sartona, o čemž svědčí recenze Sartonova díla Introduction to the History of Science. ${ }^{34}$

Druhý článek ${ }^{35}$ podává souhrn matematiků a astronomů narozených v českých zemích nebo v nich působících a jejich rozdělení na tři skupiny: nadprůměrné pokrokové osobnosti, ${ }^{36}$ misionáře v mimoevropských zemích zabývající se astronomickými pozorováními a autory učebnic a kalendářr.

\section{Otto Seydl}

Narodil se 5. května 1884 v Merklíně u Přeštic. V letech 1903-1904 studoval na české vysoké škole technické, v letech 1904-1907 na Filozofické fakultě české univerzity v Praze. Studia ukončil státní zkouškou učitelské způsobilosti pro střední školy z fyziky

27 Tamtéž.

28 Quido VeTter, Vývoj matematiky v českých zemích od r. 1620 do konce 17. století, Sborník pro dějiny př́rodních věd a techniky 6,1961 , s. 211-220.

29 TÝž, Matematické vědy v klášterech jezovitských na pưdě republiky Československé, Časopis pro pěstování matematiky a fysiky 64/6, 1935, s. 263-264.

30 Tŕž, Vývoj matematiky, s. 211-220.

31 TÝž, Sest století matematického a astronomického učení na universitě Karlově v Praze, Věstník KČSN, tř́ída matematicko-přírodovědecká, 1952, č. XIV; TÝž, Dějiny matematických věd v českých zemích od založení university $v r .1348$ až do $r$. 1620, Sborník pro dějiny př́rodních věd a techniky, 4, 1958, 80-95.

32 TÝž, Vývoj matematiky, s. 212.

33 Tamtéž, s. 211.

34 Quido Vetter (rec.), G. Sarton: Introduction to the History of Science. Vol. I: from Homer to Omar Khayyam. 1927, XII, 839 str., Časopis pro pěstování matematiky a fysiky 57/2, 1928, s. 161-163.

35 TÝž, Matematické vědy.

36 „přerůstaji běžný průměr a snažili se v mezich tehdejšich možností přinésti něco nového do moře vědeckých poznatkü“ (Tamtéž, s. 263). 
a matematiky v roce 1908 . V letech 1909-1920 vyučoval na obchodní akademii v Českých Budějovicích. Od roku 1921 byl pracovníkem Státní hvězdárny a správcem administrativy ondřejovské hvězdárny. Začal se zabývat stelární statistikou a v roce 1924 získal doktorský titul. V roce 1930 uspořádal archiv Státní hvězdárny, sahající až do roku 1775, a zaměřil se na její historii. Po odchodu Františka Nušla do penze v roce 1938 byl jmenován správcem Státní hvězdárny. Během nacistické okupace byl jako osoba „politicky nepřijatelná“ této funkce zbaven, ale zůstal pracovníkem ústavu. Po válce mu byla funkce správce vrácena a v roce 1947 se stal ředitelem. V roce 1948 byl direktivně poslán do výslužby a odešel $\mathrm{Z}$ veřejných funkcí. ${ }^{37}$

K Seydlovým šedesátinám v roce 1944 otiskla Řiše hvězd článek, ${ }^{38}$ o jeho následujícím životním jubileu však už v témže časopise není ani zmínka, otištěn je až nekrolog v roce 1959. Seydl v roce 1948 zmizel $\mathrm{z}$ veřejného života, ale dál pracoval v knihovně a archivu Státní hvězdárny. Během 50. let publikoval několik rozsáhlých článků o historii meteorologie a astronomie $\mathrm{v}$ Klementinu. $\mathrm{V}$ roce 1952 byl přizván $\mathrm{k}$ pracovní skupině pro studium dějin techniky při historickém oddělení Československo-sovětského institutu. V roce 1955-1958 byl zaměstnán v Hydrometeorologickém ústavu v Praze. ${ }^{39}$ Zemřel 15. února 1959.

Témata Seydlových prací souvisejících s Klementinem lze rozdělit do několika okruhů: dějiny pražské hvězdárny (1750-1850) ${ }^{40}$ první ředitelé Antonín Strnad (1746-1799) ${ }^{41}$ a P. Alois Martin David (1757-1836), ${ }^{42}$ hodiny a př́stroje. 43

Studie Knihovna astronoma Antonína Strnada (1746-1799) s 50stránkovým seznamem knih je ojedinělá svým přesahem do bibliografie. Seydl v původním soupisu knihovny pořízeném před Strnadovou smrtí identifikoval dva typy Strnadova písma a konfrontoval Strnadův původní soupis knih se svazkovým katalogem Strahovské knihovny. ${ }^{44}$ Seydlův seznam vykazuje dle pozdějších bibliografických výzkumů chyby, obsahuje však tituly, jejichž existenci Seydl zjistil z bibliografií knih z oboru exaktních věd. ${ }^{45}$

V roce 1951 Seydl vydal rozsáhlý článek o historii Matematického muzea, ${ }^{46} \mathrm{v}$ němž podává rozbor dostupných primárních zdrojů včetně inventárních seznamů a zpráv cestovatelů, kteří navštívili Klementinum. Dále se soustředí na tvorbu hodináře Johannese Kleina

37 Pozůstalost Otty Seydla.

38 Bohumil ŠTERnBERK, K šedesátinám Otty Seydla, ̌̌íše hvězd 25/5, 1944, s. 93-95.

39 Pozůstalost Otty Seydla.

40 Otto SEYdL, Z nejstaršich dějin pražské hvězdárny, Praha 1938.

41 TÝž, Knihovna astronoma Antonína Strnada, ředitele pražské hvězdárny (1746-1799), Praha 1939 (Publikace pražské hvězdárny č. 13); TÝž, Vědecká a buditelská činnost král. astronoma Antonína Strnada, Praha 1946; TÝž, Meteorologie v ročenkách astronoma Antonína Strnada, ředitele Pražské hvězdárny (1746-1799), Meteorologické zprávy 3/1, 1949, s. 3-7.

42 TÝž, Briefe Franz Xaver Freiherrn von Zach, Direktors der herzoglichen Sternwarte am Gotha-Seeberg und seines Nachfolgers Bernhards von Lindenau von 1791-1816 an P. Martin Alois David, Adjunkt und Direktor der königlich Prager Sternwarte, Praha 1938; TÝž, Soupis védeckých prací P. Martina Aloise Davida, ředitele pražské hvězdárny, Věstník Královské české společnosti nauk, třída matematicko-př́rodovědná, 1952.

43 TÝž, Hodiny na Pražské hvězdárně v minulosti (1777-1842), Praha 1945; TÝž, Hodiny, hodináři a časová služba Pražské hvězdárny (1778-1842), Praha 1945; TÝž, Prodej př́strojů Pražské hvězdárny ředitelem J. J. Böhmem.

44 Michaela KouklovÁ, Knihovna astronoma Antonína Strnada, Scripta Astronomica 4, 1989, s. $23-26$.

45 Tamtéž, s. 25.

46 O. SEydL, Dějiny. 
a vliv Josepha Steplinga a jeho „moderních názorư “47 na rozvoj experimentální fyziky mezi jezuitskými učenci a modernizaci jezuitského školství. Seydl vícekrát připomíná stěhování muzejních sbírek do menších místností z důvodu rozšiřování univerzitní knihovny v roce 1931 jako další v řadě změn, které se nepříznivě dotkly Matematického muzea. K první změně k horšímu podle Seydla došlo po roce 1773, když se muzeum stěhovalo z pěti do tří místností z důvodu odstoupení dvou místností univerzitní knihovně. Dále se soustředí na prodej př́strojů z Matematického muzea, ,kam je vřadila pečlivá a pietní ruka jesuitů nebo pozdějších členů hvězdárny“. 48

Publikace ukazují na pozitivistický přistup s ojedinělými znaky nově nastupujícího Koyrého paradigmatu; Seydl pečlivě studuje primární prameny, dějiny pojímá personalizovaně a experiment považuje za nástroj rozvoje teorie, jednoznačně však identifikuje objevitele a nepřátele pokroku. $V$ př́padě prodeje části muzejního inventáře $v 50$. letech 19 . století identifikuje dřívějšího ředitele hvězdárny Kreila jako „morálního původce prodeje“49 a akcentuje zásah „nešetrné ruky ředitele Böhma“, který „si počinal v celé této věci velmi neopatrně, tak, jak si vědec počinat nemá' ${ }^{50}$ Prodejem př́strojů se Seydl zabývá velmi intenzivně a vydal o něm další článek; ${ }^{51}$ hledá první zmínky o neupotřebitelnosti př́ístrojů $\mathrm{v}$ dřívějších inventárních seznamech a kriticky hodnotí ocenění př́istrojů, při kterém nebyla vzata v úvahu jejich kulturněhistorická ani uměleckořemeslná hodnota.

\section{Zdeněk Horský}

Narodil se 11. března 1929 v Praze. Vystudoval filozofii a hudební vědu na Filozofické fakultě Univerzity Karlovy a astronomii a matematiku na Př́rodovědecké fakultě Univerzity Karlovy. Pracoval v Historickém ústavu ČSAV v oboru dějiny př́rodních věd (1956-1970), Astronomické společnosti při ČSAV (1970-1973) a Astronomickém ústavu ČSAV (1973-1988). Zemřel 8. května 1988 v Praze.

Horský navazoval na koyréovskou internalistickou tradici, udržoval kontakty se zahraničními historiky vědy a jeho práce byly na úrovni tehdejších zahraničních badatelů. Zabýval se zejména novověkou historií astronomie v českých zemích. Mnoho pozornosti věnoval Johannu Keplerovi a Tadeáši Hájkovi z Hájku. Dalším oborem jeho bádání byly historické astronomické př́stroje, mimo jiné tychonské sextanty Erasma Habermela a Joosta Bürgiho z klementinských sbírek, které se dnes nacházejí v Národním technickém muzeu. ${ }^{52}$ Tématu jezuitské vědy se však obecně vyhýbal.

V kolektivním díle shrnujícím dějiny exaktních věd v českých zemích z roku 1961 Horský uvádí, že ,po polovinè 17. století znova poněkud oživá astronomická práce“"53 a jako

47 Tamtéž, s. 8.

48 Tamtéž, s. 35.

49 Tamtéž, s. 32.

50 Tamtéž, s. 36.

51 Otto Seydl, Prodej přistrojů Pražské hvězdárny ředitelem J. J. Böhmem.

52 Zdeněk Horský, Bürgiho sextant ve sbírkách NTM, Sborník Národního technického musea v Praze 5, 1968, s. 280-300; TÝž, Sextant Tychona Brahe ve sbirkách NTM v Praze, Zprávy Československé společnosti pro dějiny věd a techniky 22/2, 1965, s. 46-49.

53 Luboš Nový - Jaroslav Folta - Zdeněk Horský - Irena Seidlerová - Josef Smolka - Mikuláš Teich, Dějiny exaktnich věd v českých zemích do konce 19. století, Praha 1961, s. 70. 
její představitele jmenuje světského profesora pražské univerzity Jana Marka Marci z Kronlandu a jezuity Valentina Stansela a Jana Zimmermana. Zdůrazňuje konformitu jezuitských vědců církevnímu zákazu heliocentrismu, která se projevovala tím, že se tomuto tématu vyhýbali a „mimo tuto problematiku pracují védeckými metodami a docházejí k dílč́m výsledkưm, které jsou stále ještě príspěvkem k rozvoji astronomie“ ${ }^{54}$ Tuto skutečnost přisuzuje doznívající „,tradici vyspělé vědecké práce z konce minulého obdobi, kdy u nás pưsobil Kepler a r̆ada jiných vynikajícich vědcư “. ${ }^{55}$ Astronomická práce ke konci 17. století však „ač se zabývala spiš dílči než zásadni problematikou a byla v nejužším spojenís katolickou církví, speciálně jesuitským řádem, stále ještě neztrácela spojeni se světovým vývojem astronomie“. V polovině 18. století dochází $\mathrm{k}$ „,naprosté stagnaci astronomické práce, zpưsobené ortodoxním protivědeckým zaměřením katolického kléru“. Rychlý obrat k experimentální vědecké práci, typický pro vývoj jezuitské exaktní vědy osmnáctého století, ${ }^{56}$ Horský přičítá reformě školství, omezující pravomoci církve na školách, vnitřnímu vývoji $\mathrm{v}$ jezuitském řádu a změnám jeho postojů vǔči vědě, jejichž ústředním hybatelem je Joseph Stepling. ${ }^{57}$ Ve vývoji astronomie po Steplingovi Horský vidí „určitý sklon k prakticismu“, 58 který se projevuje soustředěním práce kolem zpřesňování geografických souřadnic. Přitom zestátnění Steplingem založené klementinské hvězdárny, jejíž umístění se časem ukázalo nevýhodným a jejíž budování naráželo na nedostatek prostř̌edků v důsledku vídeňského centralismu, dle Horského na situaci nic nezměnilo. ${ }^{59}$

V knize Kepler v Praze (1980) Horský uvádí, že jezuité ,začali v astronomii důsledně dodržovat zákaz heliocentrismu. Drželi se stále Aristotelovy fyziky a přijímali a vyučovali Aristotelovy di̊kazy nehybnosti Země a jejiho postaveni uprostřed vesmiru. Tycho Brahe jim poskytl vítanou př́ležitost jakž takž začleňovat do svých výkladů aspoň některé nové objevy. “ ${ }^{0}$ Jako doklad paradoxní situace panující v jezuitské vědě uvádí vpisek jezuitského knihovníka na exempláŕi Rudolfínských tabulek v univerzitní knihovně v Olomouci: „Autor je odsouzen, ale toto dilo se připouští. 61 “

Ve studii České země a Kopernik $k^{62}$ Horský zmiňuje jezuitské učence pouze v souvislosti s prezentací kopernikanismu na pražských univerzitách. Na př́íkladech několika rukopisů Národní knihovny ČR dokládá, že heliocentrismus nebyl zamlčován, ale byl vykládán jako hypotéza bez nároku na fyzikální reálnost. Horský zmiňuje zápis fyzikálních přednášek profesora matematiky Matthea Coppylia z roku 1678, zapsaných posluchačem Františkem Housem. ${ }^{63} \mathrm{~V}$ doplňující poznámce $\mathrm{k}$ tomuto textu Horský uvádí rukopisy z Národní knihovny ČR vztahující se ke kopernikanismu. Jde o přípravy přednášek neznámého autora

54 Tamtéž.

55 Tamtéž.

56 Marcus Hellyer, Catholic Physics. Jesuit Natural Philosophy in Early Modern Germany, Notre Dame (Indiana) 2004.

57 L. NovÝ, Dějiny, s. 102.

58 Tamtéž, s. 109.

59 Tamtéž, s. 102.

60 Zdeněk Horský, Kepler v Praze, Praha 1980, s. 232.

61 Tamtéž, s. 241.

62 Zdeněk Horský, České země a Kopernik, in: Zdeněk Horský - Vojtěch Hladký - Tomáš Hermann - Iva Lelková (eds.), Koperník a české země, Praha 2011, s. 143-174.

63 Tamtéž, s. 173. Horský neuvádí signaturu. Týž rukopis je uveden v K. MAČÁK - G. SCHuPPENER, Matematika v jezuitském Klementinu, s. 74 jako DD IV 22 ve Strahovské knihovně. 
z konce 16. století s iniciálami I.V.H.R., ${ }^{64}$ který Horský zařazuje do pražského jezuitského prostředí, a zejména přednášku De preacipuis spherae mundi partibus usuque globi, cum astronomici, tum geographici, v němž je ,značně podrobně a znale vysvětlován Koperníkưv způsob řešení vesmirných pohybů. Výklad je zřejmě založen na přmé a dosti hluboké znalosti Koperníkova díla." ${ }^{65}$ Horský konstatuje, že autor vyvrací heliocentrismus autoritou Písma svatého a dalšími argumenty, ale přesto byla jeho podstata vykládána posluchačům poměrně podrobně. ${ }^{66}$

\title{
7. Závěr
}

Všichni čtyři zmínění badatelé nepřipisují jezuitům zvlášt' progresivní názory v otázkách stavby sluneční soustavy, snad s výjimkou Steplinga. Opomíjejí přitom stropní fresku v Novém matematickém sále, který byl jednou z místností muzea. Na fresce je hvězdné nebe a klementinská věž v dnešní podobě, tedy po Steplingově úpravě v letech kolem 1755. Kolem každé hvězdy krouží několik planet a u některých hvězd jsou znázorněny i komety na parabolických drahách. Je ovšem třeba připomenout, že o existenci planetárních průvodců hvězd byl přesvědčen na základě vlastních pozorování v letech 1776-1777 moravský rodák, jezuita Christian Mayer (1719-1783), který v roce 1778 publikoval průkopnické dílo - seznam sedmdesáti dvou převážně jím objevených hvězd s průvodci 67 a v roce 1781 kata$\log 80$ těchto podle dnešní terminologie dvojhvězd. ${ }^{68}$ Mayer působil na dvoře osvícenského kurfiřta Karla Theodora (1724-1799), pro něhož vybudoval hvězdárny ve Schwetzingen a v Mannheimu. Představu plurality světů zastávali Giordano Bruno, René Descartes a Leonard Euler a výskyt této představy v Klementinu svědčí o odvážně moderních názorech pražských jezuitů. ${ }^{69}$

Poděkování: Děkuji Janu Matěji Rakovi za možnost nahlédnout do pozůstalosti Otty Seydla.

\section{PETRA HYKLOVÁ}

\section{Das Erbe der exakten Wissenschaften des Klementinums und das zweite Leben des „Musaeum mathematicum“ im 19. und 20. Jahrhundert}

\author{
ZUSAMMENFASSUNG
}

Dieser Beitrag behandelt Zeugnisse der wissenschaftlichen Tätigkeit von Mitgliedern der Societas Jesu des Prager Klementinums und ihre Rezeption durch ältere Wissenschaftshistoriker: Josef Smolík (1832-1915), Quido

64 Horský uvádí signatury XII F 25 a XII F 28.

65 Z. HoRsKÝ, České země a Kopernik, s. 174.

66 Tamtéž.

67 Gründliche Vertheidigung neuer Beobachtungen von Fixsterntrabanten welche zu Mannheim auf der kurfürstl. Sternwarte entdecket worden sind, Mannheim 1778.

68 De novis in coelo sidereo phaenomenis in miris stellarum fixarum comitibus Mannhemii, Mannheim 1779.

69 Výzkum byl podpořen Grantovou agenturou Univerzity Karlovy (projekt č. 1152216). 
Vetter (1881-1960), Otto Seydl (1884-1959) und Zdeněk Horský (1929-1988). Im Rahmen der Materialmenge, die diesen Historikern zur Verfügung stand, wird an die Geschichte des einst international bekannten Mathematischen Museums im Klementinum erinnert, das 1785 aufgehoben wurde; ein Teil seines Inventars aber befand sich noch im 20. Jahrhundert in den Räumen der Staatlichen Sternwarte des Prager Klementinums.

An die Arbeiten dieser Wissenschaftshistoriker, die die exakten wissenschaftlichen Tätigkeiten der Jesuiten und ihrer Nachfolger im Klementinum betreffen, soll hier wertend erinnert werden. Die Biographie Quido Vetters wird anhand von Archivrecherchen präzisiert. Die Biographie Otto Seydls wird anhand von Materialien aus seinem Nachlass ergänzt, außerdem fasst der Beitrag jene Publikationen Otto Seydls zusammen, die mit der Geschichte des Klementinums zusammenhängen. Die positivistisch orientierten Historiker Smolík und Vetter schenkten der jesuitischen Wissenschaft nur minimale Aufmerksamkeit und schrieben ihr keine Bedeutung zu; Smolík bezog in seine Übersicht über die Mathematiker der böhmischen Länder nicht einen einzigen Jesuiten ein, während Vetter nur kurz auf die Jesuiten eingeht und ihnen im Rahmen der Möglichkeiten begrenzte Bemühungen um wissenschaftliche Forschung zugesteht.

Otto Seydl, dessen ursprüngliche Orientierung die stellare Statistik war und der sich dann historischen Beobachtungen und dem Archiv der Sternwarte des Prager Klementinums zuzuwenden begann, widmete mehr als ein Dutzend Arbeiten der Geschichte der exakten Wissenschaften im Prager Klementinum. Unter anderem befasste er sich mit der meteorologischen Reihe des Klementinums, mit der Bibliographie Antonín Strnads, Direktor der Sternwarte des Klementinums, veröffentlichte Strnads erstes Inventarverzeichnis des Mathematischen Museums und identifizierte (Kleins) erdkundliche Uhr, die er zeitlich einordnete. Er konzentrierte sich auf die Frühgeschichte der Astronomie und Meteorologie im Klementinum, d.h. auf die Zeit von 1750 bis 1850, und auf bedeutende Persönlichkeiten und den zeitlichen Dienst im Klementinum. Zdeněk Horský, eine markante Persönlichkeit der tschechischen Wissenschaftsgeschichtsschreibung, befasste sich nur am Rande mit den exakten Wissenschaften der Jesuiten, und zwar im Rahmen von Untersuchungen zur Rezeption des Kopernikanischen Heliozentrismus in den böhmischen Ländern. Alle diese Forscher gestehen den exakten Wissenschaften der Jesuiten keine besondere Bedeutung zu, auch wenn ihnen die beiden zuletzt Genannten das Bestreben um Fortschritt im Rahmen der Einschränkung durch kirchliche Dogmen einräumen.

Deutsche Übersetzung Wolf B. Oerter

\author{
Petra Hyklová \\ Astronomický ústav MFF UK \\ petra.hyklova@gmail.com
}




\section{Príloha}

\section{Seznam předmětů v cís. král. muzeu matematickém ${ }^{70}$}

\section{Vstupní místnost \\ Skřín po pravé straně dveří, obsahující následující katoptrika:}

A 1. Válcové zrcadlo Branderovo ${ }^{71} \mathrm{~s} 12$ proměnnými obrázky a 7 pro menší zrcadlo.

A 2., 3. Zrcadla rovněž válcová se dvěma portréty na dřevě, zobrazujícími Alexandra a Aristotela.

A 4. Zrcadlo celé z kovu.

A 5. Záhadný stroj Branderův se 6 obrazy.

A 6. V dřevěné skř́ince prŕíslušných 6 obrazů.

A 7. Kovové zrcadlo duté, zvětšující.

A 8. Zrcadlo duto-vypuklé.

A 9. Zrcadlo dvacetistěnné, skleněné, pro zmnožování předmětů.

A10. Malé měděné parabolické zrcadlo ze žluté destičky.

A11. Rovněž jiné.

A12., 12., 12., Zrcadlo vypuklé, duté a duté.

A13. Zapalovací sklo vypuklé a dvě jiná ploskovypuklá, neuzavřená ve dřevě a jedno proděravělé.

A14. Zapalovací sklo mnohostěnné.

A15. Zapalovací sklo dvojvypuklé.

A16. Rovněž zapalovací sklo.

A17.-A25. Jednoduché drobnohledy s nějakými předměty, podloženými již pod sklem.

A26. Složený drobnohled, z mosazi.

A27. Jiný lepší, ne z mosazi.

A28.-A31. Rovněž.

A32., 35., 35. Tři mnohostěnná skla, dvě v trubkách, třetí uzavřené ve dřevě.

A33. Jiné mnohostěnné sklo s 5 obrazy.

Tato skřín obsahuje 45 kusů.

A34. Dvě parabolická zrcadla u okna; rovněž Muschenbroekův pyrometr zároveň se 4 kovovými tyčinkami, sloužícími k pokusům.

\section{Jiná zasklená skřín}

Ta obsahuje: 24 skleněných trubek různého druhu k hydrostatice. Níže jsou nějaké předměty k vývěvě, jako tři skla duto-vypuklá, rovněž 4 jiná, 5 klapek pro zkoušení zvuku a tlaku vzduchu, trojité magdeburské polokoule, dva mramorové kruhy, měděné kruhy k vývěvě, recipienty k pokusům o tlaku vzduchu, globus měděný a skleněný, také 8 recipientů.

70 Publikováno jako př́loha Otto SEYDL, Dějiny jesuitského, Musea matematického ‘v koleji sv. Klimenta na Starém městě v Praze, Věstník Královské české společnosti nauk, třída matematicko-přírodovědná, 1951, č. VII. $\mathrm{Z}$ latiny přeložila Ph.C. Jaroslava Hemerková.

71 Georg Friedrich Brander (1713-1783), mechanik v Augsburgu. 
A38. Laterna magica s 30 obrazy papírovými a 89 skleněnými destičkami, dílem pomalovanými, dílem ještě nepomalovanými.

A39. Magická lampa k ohlašování nočních hodin.

A40. Vývěva.

A41. Pumpa.

A42. Heronova bán̆.

A43. Elektrický stroj Rennerův, k němuž náleží tyto součástky: dvě tzv. filosofické baterie; elektrometr Branderův; měděný moždíř pro zápalný plyn; též skleněná lahvička Tučkova; skleněná nádoba pro tryskající vodu; malý skleněný kotouč k pozorování cesty elektrické jiskry; lahvičky k uschovávání zlaté niti; jednoduché zvonečky, s dráty a jiskrami; se šestistopým plechovým svodičem; s podnoží a podložkou; s červenými hedvábnými nitkami kombinovanými.

A43. znovu. Elektrofor s vlastním zesilovačem a Rennerovou poduškou. Skleněné recipienty: 8 zavřených, větších i menších, 4 otevřené.

\section{Skřín podobná první, obsahuje tyto geometrické přístroje:}

B 1.-7. Libely a měřítka různého druhu, také pro potřebu pyrotechniky.

B 8. Mosazný geometrický kruh, dělený ve své stupně, k měření úhlových vzdáleností.

B10. Mosazný kruh, obsahující Pythagorovu tabulku.

B11. Pyrotechnický př́stroj.

B12., 13. Jednoduchý transportér s průzory a druhý bez nich.

B14.-17. Průzory s magnetkou na zpo̊sob goniometrika.

B18. Př́istroj k dělení měřítek.

B19. Mosazný kvadrant.

B20. Pevné mosazné pozlacené kružidlo k dělení.

$\mathrm{B} 21$. Magnetka, uzavřená $\mathrm{v}$ dřevěném pouzdře.

B22. Železné kružidlo, jako B20. Rovněž B25. Pevné kružidlo ze železa, jako B20.

B23., 24. Geometrické kř́̌že.

B26. Větší průzory.

B28. Dřevěný geometrický kvadrant.

B29.-31., 34., 36.-40. Proporcionální kružidla.

B32. Rovnoběžné pravítko.

B41., 42., 44. Kružítko goniometrické a pyrotechnické.

B43. Trojúhelník rovnoramenný s pravítkem, rovnoběžným se základnou.

B45. Kosočtverečné pravítko.

B46. Pravítka složená na způsob rovnoběžnostěnu.

B47. Pravý úhel s kvadrantem.

B48., 49. Př́́stroje k perspektivě.

B50. Válec se stopou pražskou, římskou, norimberskou atd., pozlacený, [ukazující i] průměry globů, tabulku Pythagorovu. Části válce, spojené články, slouží pro inkoust, křídu, atd.

B51. Pozlacený rovnoběžnostěn s rozmanitými stopami (antverpskou, kolínskou, norimberskou, rrímskou); svrchu je neprovrtaný kruh.

B53., 54. Stopa vídeňská a římská na pozlaceném proporcionálním kružidlu. 
B52. Chronologický válec z pozlacené mědi, obsahující měsíce a dny, písmena nedělní, ukazuje východy a západy Slunce atd.

B56. Proporcionální kružidlo na průměry a zvětšování částí, když je dána velikost úsečky, pozlacené.

B59. Dvě nohy k starodávnému radničnímu stolku.

B60. Otáčivý stolek s průzory.

B61. Mosazný měřící řetěz.

B62. Větší dřevěné kružidlo s dělením, rovněž kalibry.

B63. Železný rovnoběžnostěn.

B64., 65. Dva pantografy, měděný a železný.

Obsahuje tedy tato skřín 65 kusů. Mimo to jsou níže nějaké kusy, jež by opětně mohly sloužiti k užitku. V okenici prvního okna téměř vše pro sluneční drobnohled.

\section{Prostřední místnost \\ První skřín u dveří prostřední místnosti po pravé straně, obsahující prístroje astronomické a gnomonické}

C 1. Krásný stříbrný zemský globus, jejž podpírá Atlas. Nahoře armilární (kruhová) koule.

C 2. Malá nebeská koule z pozlaceného plechu.

C 3. Armilární (kruhová) koule.

C 4. Universální astrolabium Gemmy Frisia, ${ }^{72}$ jedno menší, jedno větší.

C 5. Astrolabium, které sestrojil G. Hartmann, zhotovené v Norimberku 1532, je podobné předešlému.

C 6. Universální astrolabium D. de La Hire. ${ }^{73}$

C 7. Astrolabium, jako u předešlého; dole dva kvadranty se žlutým sklem.

C 8. Taktéž jiné.

C 9. Větší měděný kvadrant.

C10. Pozlacený kvadrantík z mědi, rozdělený na $90^{\circ}$. Taktéž níže malý.

C11. Měděný kvadrant s jinými pomůckami, opatřený ke studiu staré astronomie.

C12. Zlomek př́stroje geograficko-astronomického.

C13. Měděný kvadrant.

C14. Armilární (kruhová) koule bez podstavce.

C15. Větší kruh, určující hodiny.

C16. Menší kruh, určující hodiny.

C17. Podobná armilární (kruhová) koule, znázorňující soustavu Slunce a Měsíce; viz Puerbach. ${ }^{74}$

C18. Soustava Jupiterova podle mínění Tychonova, viz Puerbach.

C19. Přístroj ke kreslení slunečních hodin s ukazovatelem stínu. NB. Zhotovený v Praze 1598 Erazimem Habermelem. ${ }^{75}$

C20. Universální hodiny Engelbrechtovy (vyměněny).

72 Gemma Frisius (1508-1555), nizozemský lékař, matematik, přírodovědec a mechanik. Působil na univerzitě v Leuvenu.

73 Philippe de La Hire (1640-1718), malír, architekt a matematik v Paříži.

74 Georg (von) Peuerbach (1423-1461), matematik a astronom na vídeňské univerzitě.

75 Erazim Habermehl (?-1606), hodinář z Norimberku, od r. 1594 dvorní mechanik císaře Rudolfa II. 
C21. Bicí hodiny Ant. Brauna z Frankfurtu.

C22. Pozlacený košíček; také podobný dřevěný.

C23. Hodiny složené z jednoduchého a eliptického horizontu.

C24. Jiné větší hodiny pro šiř́ku Vídně $48^{\circ} 22^{\circ}$ od Melchiora Oty.

C25. Hodiny horizontální a vertikální, orthogonální, postavené na sebe, z kosti a slonoviny.

C26. Hodiny stříbrné, s obou stran pozlacené.

C27. Pozlacené hodiny v polokouli.

C28. Pozlacené hodiny s větrnou růžicí.

C29. Hodiny rovnodennostní.

C30., 31. Pozlacené hodiny v podobě knížky, jako C25.

C32. Hodiny z ebenového dřeva čínského.

C33., 34. Hodiny v měděném a dřevěném válci.

C35. Hodiny duté, pozlacené. Hodiny sluneční a měsíční, zhotovil 1588 Petr Purmann v Mnichově.

C36. Dřevěné hodiny rovnodennostní se šlechtickým erbem.

C37. Hodiny dřevěné ve tvaru hvězdy.

C38. Hodiny jako C25.

C39. Skleněné hodiny.

C40. Měděné hodiny.

C41. Hodiny rovnodennostní.

C42. Skleněné hodiny.

C43., 44. jsou zlomky nějakého př́stroje.

Tato skřín obsahuje kusů počtem 48.

\section{Druhá skříň u kamen pokračuje s těmito předměty:}

C45. Sluneční hodiny; také C46.

C47. Astronomický kvadrant k zjištování výšek hvězd.

C48.-50., 52., 54., 56., 63., 66. Hvězdné hodiny.

C51. Př́stroj, zhotovený Erazimem Habermelem v Praze pro Tychona.

C53. Zlomek téhož.

C55. Zlomek přístroje, oznamujícího lícem stínů napsané hodiny, jež se rubem stínů vpisují do válce; obsahuje zároveň geometrický čtverec.

C57. Hodiny v trojúhelníku.

C58., 59. Obyčejné hodiny.

C60. Kružidlo k označování hodin.

C61. Přístroj k vyznačování slunečních hodin na zdi. Rovněž C67.

C62. Kvadrantík.

C64. Kvadrantík ve vertikální rovině.

C65. Pozlacený polokruh s pravítkem.

C68. Rovnoramenný trojúhelník.

C69. Neúplná destička do hodin. Rovněž tři měděné destičky $\mathrm{k}$ automatickým hodinám Tychonovým a tři jiné. 
1. Geografické hodiny.

2. Hodiny podle soustavy Koperníkovy.

3. Hodiny Tychona Brahe.

4. Astronomicko-chronologické hodiny Trauttmandorfské.

5. Obyčejné hodiny se zvonky.

6. Perpetuum mobile s nekonečným závitem.

7. Př́ístroj $\mathrm{k}$ dělení astronomických kvadrantů.

8. Tychonův sextant.

9. Staré planetárium.

10. Nebeská koule.

12. Anglický tlakoměr.

13. Hodiny se žábou.

14. Nebeská koule Kleinova.

15., 16. Bleauovy globy.

17. Př́stroj centrobarický.

18. Magnet s kotvou.

19. Varhany.

20. Píštalka Kleinova. Cembalo, nad nímž je př́stroj, pohybující očima podle kyvů hodin.

21. Kytara.

22. Jiné cembalo.

23. Jiné se zvonečky.

24. Housle ze slámy.

25. Bicí kotel (tympán) s automatickým krytem.

26. Had v lihu.

\section{Třetí místnost}

Mezi dveřmi je zasklená skřín̆, obsahující v hořejší části:

1. Čínské štětce ve vlastním pouzdře, zabalené do čínského papíru.

2. Krabice s 8 tabulkami pravé černé čínské tuše, štětcem ku psaní a nožíkem ve vlastním pouzdře.

3. Čínský cestovní pas ve čtvercové měděné destičce.

4. Kusy čínské mince spolu s dvojitými vahami.

5. Část čínského „pensiu“.

6. Čínská vějička ze slonoviny.

7. Čínská žlutá porcelánová miska spolu s nožem, dvěma tyčinkami a třemi jinými kusy $\mathrm{k}$ tomu náležejícími.

8. Hřeben $\mathrm{z}$ jednoho kusu dřeva, jiný z indického bambusu.

9. Dřevěné pouzdro se stř́brnou lžíí a jinými dvěma kousky stříbra, sloužícími k užívání v Číně.

10. Jiné pouzdro se složením téměř týmž jako je čínské „,pensiu“.

11. Ženský náhrdelník z českých skleněných korálků.

12. Stř́brná jehla s housličkami. 
13. Dva třtinové kratiknoty; 2 dřevěné desky k sv. přijímání.

15. Zrna pižmová.

16. Štáva (?)

17. Brazilská pšenice.

18. Pravděpodobně nějaký druh laku či fermeže.

19. Brazilské arrow-foot $\mathrm{z}$ rostliny Manihot utilissima.

20. Tapioka (z Manihot util.) osvěžující (posilující).

21. Západní kameny (?).

22. Pražená mouka (patrně $\mathrm{z}$ arrow-root).

23. Nádobka s čajem $z$ Paraguaye.

24. Jiná nádobka s čajem indickým.

25. (?)

26. Kakaové boby.

27. Balsám brazilský.

28. Semena cedru.

29. Plody (?)

30. (?)

31. Pryskyřičná vlákna (?)

32. Vlákna palmová.

33. Tamarind (strom z čeledi Leguminos, dává drogu pulpa Tamarindorum).

34. (?)

35. Čtyři vlasy z něčí hlavy z Paraguaye.

36. Semeno malého česneku (?)

37. Patrně jedovatý kmín.

38. Divoký indický ořech.

39. Patrně muší kř́́dla z Quita.

40. Zub krokodila.

41. Uši mořské krávy.

43. Jazyk ryby...

44. Chameleon.

45. Jazyk a drápy amerického medvěda.

\section{$V$ nižší části téže skříně}

Hůl ze slonoviny, opatřená závity; čtyři kloboučky z indického peř́; 1 z hedvábí, 2 ze slámy. Činské hedvábné závěsy, menšich 16, větši 2.

Vlněný [?] šáteček z živočichova uranga (tapiti - brazilský zajíc); dva jiné šátečky vyšívané. Stromová kůra, kterou se odívají Indiáni.

Ořechy kokosové.

Nákrčník. Modré závěsy.

Dva podlouhlé obrazy čínské.

Též knížka s malbami čínskými. Krátký čínský katechismus.

Čtyři svazky o pověře Čiňanů, jiných 5. Papirový vioz pátera Schalla. ${ }^{76}$

76 P. Johann Adam Schall von Bell SJ (1592-1666). Astronom, misionář a mandarín v Číně. Podílel se na reformě čínského kalendáře. 


\section{Naproti této $v$ hořejší části skříně}

2 mužské figury z lastur. 2 čínské modly, 1 indická, 1 česká.

Pštrosí vejce.

Kř̌ž místo meče.

Kalamář a posýpátko z mořských lastur.

Čínský růženec z cukru.

Dvě umělé oči a ucho ze slonoviny.

Ukřrižovaný ze slonoviny.

Sošky Panny Marie. Jezulátko z porcelánu.

Čepice a schránka z kokosového ořechu. Tři indické tkaniny.

Obraz P. Segnera; ${ }^{77}$ též hraběte St. (?); šálky z lipového dřeva.

\section{$V$ dolení části skříně}

Na 3000 obrazů různého druhu; také na 4000 jiných. Mezi těmito malby v knize k návratu misionáře ze San Jaga, v knize obsažené.

\section{Uprostřed místnosti}

Hoření skřín obsahuje nádobí; uprostřed 6 váz, 2 schránky a konvičku, tři číše z kopyta zvířecího.

Dolení: kusy mírek a mírky z vosku, sádrovce a několik z alabastru. Na zdi je 40 českých ptáků.

Mezi okny: větší skřriň elegantně vypracovaná, v níž jsou pospolu 3 páry starodávných střevíců, dřevěný řetěz a nějaké drobnosti.

Pátera Verbiesta ${ }^{78}$ Ephem[eridy?] a čínské evangelium Páně.

Obraz hodovníka.

Branderovy hydrostatické libely.

Arabský korán.

Deník velikého vezíra.

V pravém okně dva optické př́stroje s jednoduchými obrazy.

V levém vojáci, kráčející podle taktu tympánu. Naproti dvě skř́ně se sbírkou mincí, mezi nimiž je znamenitý zlat'ák Alexandra Galeata.

V levé především stř́brný peníz Josefa I., kurfirta saského, Karla a Maxmiliana. Níže ruský zlatý rubl. NB. Zatím co jsem byl ve Vídni, ztratil se! U oken dvoje kyvadlové hodiny, s obou stran ryba s 1 rohem, pohlavní úd velryby, luk, husitská sekera, halapartna Plachého, dva meče.

Na zdi obzvláště obraz Magdaleny a Ecce Homo ze spirály [?].

77 P. Ján Andrej Segner SJ (1704-1777). Profesor matematiky, fyziky a chemie v Jeně a Göttingenu.

78 Ferdinand Verbiest (1623-1677). Misionář v Číně. Astronom, matematik a mechanik. 


\section{V odpočívárně}

Portréty menší i větší, postoupené knihovně79

Ve foliovém formátu:

1. Císařové, králové.

2. Papežové, kardinálové.

3. Vévodové a knížata.

4. Vojenské osobnosti.

5. Šlechtici.

6. Theologové a pastoři.

7. Vzdělanci a umělci.

8. Slavné ženy.

9. Osoby různého stavu.

10. Moravští a čeští učenci, rytiny Balzrovy.

V kvartovém formátu:

1. Císařové, králové, kurfiřti.

2. Papežové, kardinálové.

3 . Vévodové a knížata.

4. Vojenské osoby.

5. Šlechta.

6. Theologové a pastoři.

7. Spisovatelé a umělci.

8. Slavné ženy.

10. Osoby různého stavu.

11. Svázané různé otisky portrétů.

12. Augšpurské. Rantzův Eremitor.

Christ. I., II., taktéž v kvartu I., II.

Evangel. 200.

Lane[?] 200.

Zeichenbücher.

Vado mori.

Wunderswerke Goldersovy.

201 svatý obraz.

202 různé.

9 modelů.

Architektonické věci.

V osmerce:

Francouzské portréty Desroches I., II.

3. Císařové, králové, kurfiřti.

4. Papežové, kardinálové, biskupové, řeholníci.

5. Vévodové a knížata.

79 Univerzitní knihovna. 
6. Vojenské osobnosti.

7. Šlechta.

8. Theologové, pastoři.

9. Učenci a umělci.

10. Osoby různého stavu.

11. Slavné ženy.

Biblická historie s růz., 202 kusy. (orig.: Historia biblica cum variis N.)

Různé 300.

Porticus religiosa 200 .

2 díly Thesaurus historiae sacrae.

Herbár.

Fürstlichen Baumeister Archit. civilis I., II. und Anhang.

Různé.

Saulenbuch.

Pohled na královský palác v Casertě. 